Article

\title{
Perceptions of Media Performance: Expectation-Evaluation Discrepancies and Their Relationship with Media-Related and Populist Attitudes
}

\author{
Nayla Fawzi ${ }^{1, *}$ and Cornelia Mothes ${ }^{2}$ \\ ${ }^{1}$ Department of Communication and Media, LMU Munich, 80538 Munich, Germany; E-Mail: fawzi@ifkw.Imu.de \\ 2 Media Management Department, Macromedia University of Applied Sciences, 04105 Leipzig, Germany; \\ E-Mail: c.mothes@macromedia.de \\ * Corresponding author
}

Submitted: 14 April 2020 | Accepted: 1 July 2020 | Published: 24 August 2020

\begin{abstract}
Public criticism of professional media is omnipresent in many democratic societies. This debate has often been examined concerning what the audience demands from the media (expectations) or how they evaluate media performance (evaluations). Based on a representative, quota-based online survey of the German population in 2019, this study examines citizens' expectations, evaluations, and the discrepancies between both, as well as their relationship with media trust, socio-political predispositions-particularly populist attitudes-and individual media use in high-choice media environments. Results show that citizens have high expectations of the media which they mainly do not see fulfilled and that expectation-evaluation discrepancies are related to lower media trust in the case of particularly important and/or most noticeably underperformed media functions. Both expectations and evaluations were associated with populist attitudes, but only in the case of anti-elite attitudes in such a way that increased expectations collide with negative media evaluations. For anti-outgroup attitudes, instead, the analyses show a generally negative assessment of journalistic media, both in terms of expectations and evaluations. Media use does only play a minor role.
\end{abstract}

\section{Keywords}

journalistic quality; media performance; media trust; populist attitudes; quality evaluations; quality expectations

\section{Issue}

This article is part of the issue "Media Performance in Times of Media Change" edited by Melanie Magin (Norwegian University of Science and Technology, Norway) and Birgit Stark (Johannes Gutenberg University Mainz, Germany).

(C) 2020 by the authors; licensee Cogitatio (Lisbon, Portugal). This article is licensed under a Creative Commons Attribution 4.0 International License (CC BY).

\section{Introduction}

In many Western democracies, some segments of society have become increasingly disappointed with the performance of the established media. Professional journalistic media are being criticized for disseminating 'fake news,' for being too close to the political and economic elites, and for reporting in a way that substantially diverges from what these citizens perceive as reality (Jackob et al., 2019; Ladd, 2012). These allegations address normative functions that are expected to be fulfilled by journalistic media in democratic societies, such as providing information, serving as a watchdog for society, enabling the constitution of a public forum for the exchange of ideas, or facilitating civic participation and mobilization (e.g., Graber, 2003; Schudson, 2008).

Communication research has only recently started to deal more intensively with the audience perspective on these normative media functions and to investigate, for instance, the extent to which citizens' values are congruent with key normative roles in journalism (e.g., Gil de Zúñiga \& Hinsley, 2013; Peifer, 2018). This research usually examines what users demand from the media (expectations) or how they evaluate the media's actual performance (evaluations) but has rarely analyzed both in a comparative way. This leads to the open questions 
of whether negative media evaluations are related to disappointed expectations, how expectation-evaluation discrepancies are linked to media trust, and which user characteristics are associated with specific expectations and evaluations. The present study aims to address these questions based on a quota-based online survey, representative for Germany, where accusations of the media as the 'lying press' have become increasingly loud in recent years-most of all in the wake of the surge of the populist party AfD-and have considerably undermined public trust in professional media among some groups of society (Fawzi, 2019; Jackob et al., 2019).

\section{Normative Media Functions and Media Performance}

Since professional journalistic media play a central role in shaping public discourse in modern democracies, they are required to meet high normative standards, derived from their main public service function (Norris, 2000; Strömbäck, 2005). Depending on the specificities of the democratic system at hand, the functions of the media and journalism are given different priorities (e.g., Strömbäck, 2005). The most important function of the media in a democracy is informing the public about what is going on in politics and society, which relates to normative demands on the quality of reporting, such as completeness, balance, or accuracy (Jandura \& Friedrich, 2014; McQuail, 1992; Urban \& Schweiger, 2014). In close association with this information function, mass media are also expected to create a public forum to enable deliberation in public discourse by involving all groups in society and actively mediating between political institutions and citizens. In their watchdog function, the media are additionally expected to monitor societal elites and to hold them accountable to legal and moral standards. The analysis function of the media is supposed to support citizens in making sense of the complexities of political and social developments.

It is expected that journalists provide an interpretation of current issues and report on suggestions on how to solve society's problems (Schudson, 2008; Weaver, Beam, Brownlee, Voakes, \& Wilhoit, 2006). It is also the media's task to promote social empathy by creating a sense of community and ensuring that citizens identify with the society they live in. The media are thus supposed to make citizens aware of the experiences and interests of other people, especially less privileged groups.

Finally, the mobilization function expects the media to support politically active and involved citizenship and to convey democratic norms and values (Schudson, 2008). The media should arouse interest in political issues and show citizens how they can get involved in political affairs (Schudson, 2008). These normative functions of the press are not fixed and the capacity of the media to fulfill them has often been doubted (e.g., Chomsky, 2002; Graber, 2003). The question remains, however, whether citizens as the main addressee of journalistic content, and thus normative ideals related to journalistic media, share these expectations, and how well they see them fulfilled (Peifer, 2018).

\section{Citizens' Expectations and Evaluations of Media Performance}

Research examining citizens' expectations and evaluations of media performance is usually based on journalistic role conceptions or quality criteria which again are usually derived from normative media functions. A recent study by Peifer (2018), for instance, developed a 15 -item scale of perceived news media importance, which includes both the individual as well as the overall social importance of six media functions, such as information, watchdog, and mobilization (e.g., "provide me with a daily account of what is happening in the world" or "provide analysis and interpretation of the complex problems around me"; p. 23). In the Netherlands, van der Wurff and Schönbach (2014) showed that the various journalistic role expectations and ideals, such as the information and watchdog roles, are consistently expected by citizens (but see for Asian media systems Guo \& Li, 2011; Tandoc \& Duffy, 2016). Research in the US, Sweden, and Israel found that this also holds for quality criteria such as neutrality, balance, or factuality (Heider, McCombs, \& Poindexter, 2005; Karlsson \& Clerwall, 2019; Tsfati, Meyers, \& Peri, 2006). The findings indicate that recipients have similar demands on journalism like other professional stakeholders such as journalists themselves, however, they differ concerning the importance they give to some functions, such as the watchdog or mobilizing function (Eberl \& Riedl, 2020; Hölig, Loosen, \& Reimer, 2020; Tsfati et al., 2006; van der Wurff \& Schönbach, 2014; Vos, Eichholz, \& Karaliova, 2019).

Audience perceptions and evaluations of the media that are analyzed within the framework of quality perceptions either focus on news coverage of specific topics, such as the refugee crisis (Arlt \& Wolling, 2018), the quality of specific media outlets (e.g., Arnold, 2009), or specific programs (Heise, Loosen, Reimer, \& Schmidt, 2014). An exception is research on media trust, media credibility, and media bias that has extensively examined public perception of the media in general. This research has shown that in many countries, the public does not have a very favorable perception of journalism (e.g., Ladd, 2012; Lee, 2010; Newman, Fletcher, Kalogeropoulos, \& Nielsen, 2019; Tsfati \& Ariely, 2014).

A recent study in Germany shows that users are fairly satisfied with some media performances but rather disappointed with others (BR, 2016). The majority (81\%) believe that the media publish topics that are important to society. For $76 \%$, the media offer orientation in terms of the relevance of information, and $64 \%$ agree that the media uncover political and social grievances. However, more respondents believe that the media support the establishment instead of controlling it (for other points of media criticism, see e.g., Karlsson \& Clerwall, 2019; Kaun, 2014; Prochazka \& Schweiger, 2016). 
Few studies have analyzed citizens' expectations in direct comparison to their evaluations of the same dimensions. A study by Donsbach, Rentsch, Schielicke, and Degen (2009) showed that journalists are perceived to be more intolerant of other opinions and to support socially disadvantaged people less than users would demand. In contrast, journalists are seen to be more likely to assert their own needs and to have more power and influence than users would like them to have (pp. 71-73; see also Karlsson \& Clerwall, 2019). Furthermore, studies have shown that media expectations predict media evaluations (Lambe, Caplan, Cai, \& Signorielli, 2004; Wolling, 2004) and media evaluations, in turn, are associated with more general evaluations of media trust (Schielicke, Mothes, \& Donsbach, 2014). The relationship between expectations, evaluations, and media trust is often discussed in media trust literature-following a conceptualization of media (dis)trust as a consequence of users' (disappointed) perceptions of how relevant media functions are met in actual media coverage (e.g., Hanitzsch, van Dalen, \& Steindl, 2018; Müller, 2013). Media performance evaluations are also used to measure media trust (Kohring \& Matthes, 2007). However, the relationship between performance evaluation-expectation discrepancies and media trust has barely been examined empirically (but see Prochazka's [2020] study on the influence of quality expectations and perceptions as well as their discrepancies on media trust). Against this background, our study investigates the following research questions:

RQ1: Which of the six normative media functions show discrepancies between what citizens demand from the media and their perceptions of media performance?

RQ2: How do performance expectation-evaluation discrepancies relate to overall media trust?

\section{What Matters? The Role of Political and Media-Related Characteristics}

Which individual characteristics are linked to how users evaluate and perceive the media's role in society? Following media trust research that has recently started to investigate causes and consequences more profoundly, one can distinguish between socio-political and media-related characteristics. Beyond sociodemographic variables such as age, gender, and education (e.g., Cook \& Gronke, 2001; Hopmann, Shehata, \& Strömbäck, 2015; Lee, 2010; Tsfati \& Ariely, 2014), research has shown that political ideology (Gunther, 1988; Ladd, 2012) and political interest (Fawzi, 2019; Tsfati \& Ariely, 2014) is particularly associated with media trust. More recent studies have shown that what has been called a "populist worldview" goes hand in hand with negative attitudes towards the media. Especially antielite attitudes, which are directed against politicians, are related to distrust in the media and a more negative and hostile perception of media performance (Fawzi, 2019; Mitchell et al., 2018; Schulz, Wirth, \& Müller, 2020). A reason might be that populists tend to perceive the media as part of the political elite who betray the sovereign people. This may also explain why exclusionary populist attitudes (that exclude specific outgroups such as immigrants from the ingroup of the people) are negatively associated with media trust (Fawzi, 2019).

Besides these pre-existing political attitudes, individuals' media repertoires should also relate to specific user demands and evaluations. Based on selective exposure theory, it can be assumed that the media content that is individually used substantially affects what recipients expect from the media and how they evaluate specific information or media performance in general (Mothes, 2017; Tsfati \& Peri, 2006). In today's high-choice media environments, recipients can choose from a vast range of information sources, from established mainstream media to partisan alternative media, from political sources to usergenerated content. The latter sources intensively criticize mainstream media's performance; alternative media present themselves as opposed to mainstream media (Holt, Figenschou, \& Frischlich, 2019). In this context, trust research has shown that the use of mainstream media is positively associated with media trust, while alternative media and social media use can have a negative impact (Kalogeropoulos, Suiter, Udris, \& Eisenegger, 2019; Tsfati \& Cappella, 2003). Gil de Zúñiga and Hinsley (2013), for instance, found that traditional media use goes hand in hand with a positive perception of media performance (see also Vos et al., 2019).

Moreover, a theoretical link exists between media perceptions and media-related knowledge as a central dimension of media literacy (Livingstone, 2004), as knowledge about media and journalism should enable individuals to assess media performance more elaborately (Martens \& Hobbs, 2015).. However, research related to media trust has not produced consistent results in this respect and found that media literacy can both increase and decrease media trust (e.g., Ashley, Poepsel, \& Willis, 2010; Vraga, Tully, Akin, \& Rojas, 2012).

Although media trust research provides important insights into how media evaluations can be explained, it remains an open question of how exactly media performance expectations, evaluations, and the discrepancy between both are linked to media trust. We will, therefore, refrain from formulating specific hypotheses and, instead, investigate the following research questions: Which political (political interest, ideology, and populist attitudes) and media-related (media repertoire, partisan selective exposure, and media literacy) characteristics are associated with recipients' expectations (RQ3a) and evaluations (RQ3b) of media performance, as well as the discrepancy between both (RQ3c)? Do political or media-related characteristics show higher explanatory power? (RQ4). 


\section{Method}

\subsection{Sample}

A quota-based online survey of the general German population, representative for age, gender, and education, was conducted in September 2019 via an online access panel (Dynata). Participants received an incentive in exchange for their participation. Overall, 1114 respondents completed the questionnaire. In the course of data cleaning, we excluded those respondents who finished faster than one-third of the medium time of the whole sample. This resulted in a final sample of $N=1000$ participants. The respondents were, on average, 50 years $(S D=15)$ and $49 \%$ were female.

\subsection{Measures}

Expectations of media performance: Based on normative media functions and existing research on media perfor- mance (Peifer, 2018), journalistic role ideals (Hanitzsch, 2011), and journalistic role performance (e.g., Mellado et al., 2020), we asked respondents what they demand of the media concerning six functions based on 16 items (for more details, see Figure 1): information (1 item), public forum (4 items; Cronbach's $\alpha=.81$ ), watchdog ( 2 items, $\alpha=.78$ ), analysis ( 3 items, $\alpha=.78$ ), social empathy ( 2 items, $\alpha=.74$ ), and mobilization ( 4 items, $\alpha=.88$; 5 -point scales from $1=$ does not apply at all to $5=$ fully applies). A principal component analysis revealed a onefactor solution ( $M=3.94, S D=.81$, Cronbach's $\alpha=.95)$. However, we decided to also calculate indices for the six media functions separately, based on their theoretical classification.

Evaluations of media performance: Respondents were asked to evaluate their perceptions of actual media performance by means of the same 16 items: information, public forum (Cronbach's $\alpha=.86$ ), watchdog $(\alpha=.77)$, analysis $(\alpha=.84)$, social empathy $(\alpha=.80)$ and mobilization ( $\alpha=.88$; 5-point scale from $1=$ does not ap- ...reveal political abuses and scandals. (watchdog)
...inform citizens neutrally and precisely about events in politics
and society. (information)
...explain complex issues. (analysis)

...defend the free democratic order in Germany. (mobilization)

...impart democratic norms and values. (mobilization)

...contribute to a democratic understanding that connects the entire society. (public forum)

...serve as a mouthpiece for all citizens. (public forum)

... take into account interests of disadvantaged members of society. (social empathy)

...hold political and economic elites accountable. (watchdog)

...arouse interest in political issues. (mobilization)

...guide citizens in how they can participate in political matters. (mobilization)

...give voice to people with different cultural backgrounds, religious views, and sexual orientation as well as to people with disabilities. (social empathy)

...contribute to the formation of citizens' opinions on political matters. (public forum)

...highlight similarities between different political positions. (analysis)

...serve as a mediator between politics and society. (public forum)

...offer suggestions on how to solve society's problems. (analysis)

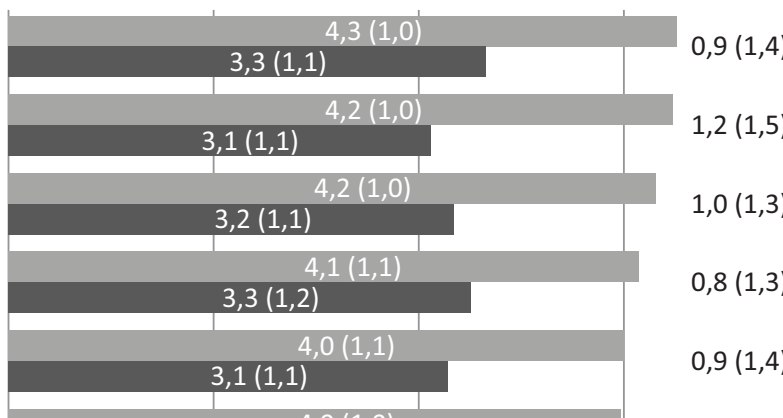

$1,0(1,3)$

$1,2(1,5)$

$1,0(1,5)$

$0,8(1,5)$

$0,7(1,2)$

$0,9(1,4)$

$0,7(1,5)$

$0,4(1,4)$

$0,7(1,3)$

$0,8(1,4)$

$0,8(1,4)$

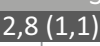

2

Expectations Evaluations

Figure 1. Citizens' expectations and evaluations of media performance in comparison. Notes: Mean values with $S D$ in parentheses; light grey values represent mean expectation-evaluation discrepancies (SD in parentheses); $862 \leq n \leq 941$. 
ply at all to 5 = fully applies). Again, a principal component analysis revealed a one-factor solution $(M=3.09$, $S D=.89$, Cronbach's $\alpha=.97$ ).

The discrepancy between expectations and evaluations was calculated as the individual difference between both ratings by subtracting evaluations from expectations.

Media trust: The overall assessment of respondents' trust in journalistic media was measured by five items adapted from Kohring and Matthes (2007), measured on 5-point scales ( $1=$ does not apply at all; $5=$ fully applies): "Relevant topics received the necessary attention" $(M=3.25, S D=1.15)$, "All important information regarding relevant topics is provided" ( $M=3.09, S D=1.13)$, "Reporting includes different points of view" $(M=2.90$, $S D=1.14)$, "The reports recount the facts truthfully" $(M=2.97, S D=1.16)$, and "The journalists' opinions are well-founded" ( $M=3.07, S D=1.09)$. Items were averaged for an overall index of media trust $(M=3.06$, $S D=1.01$, Cronbach's $\alpha=.94$ ).

Political predispositions: Political interest was measured on a 5-point scale ( $1=$ not at all, $5=$ very strong).
Respondents were asked to assess their political ideology on a left-right scale ranging from $1=$ left to $11=$ right $(M=5.88, S D=2.04)$. Following the multi-dimensional understanding of populism, we measured populist attitudes in four dimensions with individual items measured on 5-point scales from $1=$ does not apply at all to 5 = fully applies (for a full list of items and descriptive statistics, see Table 1): Homogeneity of the people ( 5 items, Cronbach's $\alpha=.75$ ), demand for people's sovereignty ( 5 items, $\alpha=.878$ ), anti-elite populism ( 8 items, $\alpha=.8$ ), and anti-outgroup populism (4 items, $\alpha=$.905; Fawzi, 2019; Hameleers, Bos, \& de Vreese, 2017; Schulz et al., 2017). We opted to analyze the subdimensions separately, as each represents populist attitudes in a specific way (e. g., "empty populism": homogeneity of the people; Jagers \& Walgrave, 2007).

Media use: The individual media repertoire was measured by asking respondents how often, on average, they use eleven different media genres for political information ( $1=$ never, 5 = daily): public-service broadcasting $(M=3.97, S D=1.38)$; private broadcasting $(M=3.42$, $S D=1.53)$; national newspapers and news magazines

Table 1. Descriptive overview of populist attitude dimensions.

\begin{tabular}{|c|c|c|}
\hline Dimension & M & SD \\
\hline Homogeneity of the people & 3.18 & 0.84 \\
\hline The people in Germany are all pulling together. & 2.53 & 1.21 \\
\hline People in Germany share common cultural values. & 3.23 & 1.08 \\
\hline If one wanted to, one could make policies that are in the interest of all ordinary citizens. & 3.62 & 1.13 \\
\hline Although Germans are very different from each other, when it comes down to it they all think the same. & 3.16 & 1.16 \\
\hline Ordinary people share the same values and interests. & 3.40 & 1.10 \\
\hline Demand for people's sovereignty & 3.90 & 0.94 \\
\hline $\begin{array}{l}\text { The people should have the final say on the most important political issues by voting on them directly } \\
\text { in referendums. }\end{array}$ & 3.92 & 1.17 \\
\hline The people should be asked whenever important decisions are taken. & 3.94 & 1.16 \\
\hline The people, not the politicians, should make our most important policy decisions. & 3.74 & 1.18 \\
\hline The politicians in parliament need to follow the will of the people. & 4.06 & 1.06 \\
\hline We need a strong head of government who can push through what the people in Germany really want. & 3.85 & 1.20 \\
\hline Anti-elite populism & 3.84 & 0.85 \\
\hline Members of parliament very quickly lose touch with ordinary people. & 4.07 & 1.01 \\
\hline Politicians are corrupt. & 3.37 & 1.22 \\
\hline Politicians make decisions that harm the interests of ordinary people. & 3.58 & 1.13 \\
\hline Politicians care about what people like me think. (reverse coded for index calculation) & 2.29 & 1.21 \\
\hline There is a large gap between the people and politicians. & 4.05 & 1.04 \\
\hline People like me do not have an impact on the government's decisions. & 3.66 & 1.20 \\
\hline $\begin{array}{l}\text { The differences between ordinary people and the ruling elite are much greater than the differences } \\
\text { between ordinary people. }\end{array}$ & 3.90 & 1.09 \\
\hline Politicians talk too much and act too little. & 4.20 & 1.02 \\
\hline Anti-outgroup populism & 3.16 & 1.25 \\
\hline Immigrants cost our country a lot of money that should rather be invested in our people. & 3.31 & 1.42 \\
\hline Immigrants are responsible for a lot of our nation's problems. & 3.07 & 1.39 \\
\hline People who are not originally from Germany have no right to receive our social benefits. & 3.00 & 1.42 \\
\hline Muslims and their religion do not fit into our culture. & 3.27 & 1.43 \\
\hline
\end{tabular}


$(M=2.67, S D=1.36)$; local newspapers $(M=3.14$, $S D=1.43)$; tabloid newspapers $(M=1.96, S D=1.13)$; newspaper websites, news magazines or public-service broadcasters $(M=3.00, S D=1.52)$; tabloid websites or private broadcasters $(M=1.96, S D=1.26)$; user comments on social media sites $(M=2.47, S D=1.39)$; social media channels of influencers, bloggers or public figures $(M=2.01, S D=1.31)$; social media channels of political actors, groups, or parties $(M=2.08, S D=1.31)$; alternative partisan media $(M=2.07, S D=1.24)$.

Partisan selective exposure: In addition to general media use, the use of congruent media coverage was measured by four items derived from Tsfati (2016), for instance, "I avoid exposure to media outlets expressing views other than my own," "I try to expose myself only to media outlets and news messages that are in line with my own attitudes." ( $1=$ do not agree at all, 5 = fully agree; $M=2.62, S D=.95$, Cronbach's $\alpha=.82$ )

Media knowledge: Focusing on media knowledge as a dimension of media literacy, six statements were presented to respondents. For each statement, respondents were asked to indicate whether they think it was true or false (e.g., "Journalists can report what they want, there are no legal restrictions."). If they chose the "don't know"-answer, this was considered a wrong answer. A media knowledge index was calculated from 0 correct answers to 6 correct answers $(M=3.86, S D=1.44)$.

Sociodemographics: Age, gender, education (recoded as 0 = lower education, 1 = higher education), and place of residence ( $0=$ West Germany, $1=$ East Germany) were additionally included in the questionnaire as control variables.

\section{Results}

When first looking at the descriptive distribution of expectations and evaluations, results show that users have high expectations regarding media performance; the majority of respondents believe that professional journalistic media should fulfill all six normative functions. Citizens first and foremost expect the media to reveal political abuse, to inform the public objectively, and to ex- plain the complexity of political issues to their audience. The majority also wants the media to take an active and mobilizing role in our democracy by defending the free democratic order and imparting democratic norms and values. Furthermore, the media should contribute to the democratic education of society as a whole and serve as a mouthpiece for all citizens. Users also expect the media to represent the interests of the disadvantaged and give them a voice so they are heard by more privileged members of society. Slightly less important but still relevant expectations towards the media concern their mediating role between politics and society and the analysis of solutions that are discussed for society's problems.

Concerning actual media performance, citizens mainly do not see these expectations fulfilled. A large part of the respondents is not satisfied with how the media perform. The discrepancy between expectations and evaluations (RQ1) varies from 1.2 scale points (neutral information and mouthpiece for all citizens) to 0.4 scale points (public opinion formation). There is not a single function that the media outperform from the recipients' point of view (see Figure 1).

Going from single items to the six dimensions of normative media functions, the most pronounced differences between these dimensions emerge on the level of user expectations (see Table 2). Particularly high expectations are found for the most traditional journalistic principles, that is, the 'information' and the 'watchdog' function. Least important to respondents-although still above the scale center-are 'public forum,' 'analysis,' and 'social empathy.' On the evaluation level, differences between the six normative functions are overall less pronounced. Respondents see all functions less represented in actual media coverage than expected.

However, all evaluation means range slightly above the center of the scale, with the 'watchdog' and the 'mobilization' functions showing the highest values. On average, evaluations deviate from expectations by one scale point, with merely small differences between individual dimensions. Only the 'information' function somewhat stands out with the largest discrepancy. However, in the case of 'information,' only one item represents the

Table 2. Repeated-measures ANOVAs on differences in mean expectations, evaluations, and evaluation-expectation discrepancies for the six dimensions of normative media functions (SD in parentheses).

\begin{tabular}{lccc}
\hline & Expectation & Evaluation & Expectation-Evaluation Discrepancy \\
\hline Information & $4.26(1.00)^{\mathrm{a}}$ & $3.06(1.15)^{\mathrm{a}}$ & $1.22(1.47)^{\mathrm{a}}$ \\
Public forum & $3.89(0.87)^{\mathrm{b}}$ & $3.04(0.95)^{\mathrm{a}}$ & $0.85(1.09)^{\mathrm{b}}$ \\
Watchdog & $4.09(0.95)^{\mathrm{c}}$ & $3.25(1.01)^{\mathrm{b}}$ & $0.85(1.27)^{\mathrm{b}}$ \\
Analysis & $3.86(0.88)^{\mathrm{b}}$ & $3.01(0.95)^{\mathrm{a}}$ & $0.87(1.12)^{\mathrm{b}}$ \\
Social empathy & $3.89(0.96)^{\mathrm{b}}$ & $3.04(1.03)^{\mathrm{a}}$ & $0.87(1.31)^{\mathrm{b}}$ \\
Mobilization & $3.95(0.92)^{\mathrm{d}}$ & $3.15(0.96)^{\mathrm{c}}$ & $0.81(1.07)^{\mathrm{b}}$ \\
Test statistics & $F(5,4635)=85.86, p<.001$, & $F(5,4370)=28.79, p<.001$, & $F(5,4295)=35.62, p<.001$, \\
& $\eta^{2}=.085$ & $\eta^{2}=.032$ & $\eta^{2}=.040$ \\
\hline
\end{tabular}

Notes: $860 \leq n \leq 928$; Means with different superscripts per construct differed significantly at $p<.05$ in repeated-measures ANOVAs with Bonferroni correction. $* * * \mathrm{p}<.001$. 
whole dimension, while larger discrepancies in individual items of other dimensions are less reflected due to the index they are part of. This particularly applies to the 'public forum'-item "serving as a mouthpiece for all citizens" (see Figure 1) and, thus, an item that in a sense reflects the counterpart of 'information' by representing the news flow from the citizen rather than towards the citizen.

How do these discrepancies translate into more general evaluations of the media as institutions that can be trusted (RQ2)? The results of the linear regression analysis in Table 3 show that media trust is significantly related to four of the six dimensions of expectationevaluation discrepancies. Specifically, higher discrepancies are linked to lower scores on media trust for the normative media functions of 'information,' 'public forum,' and 'watchdog' - hence, the three dimensions that are particularly important to users and/or most noticeably underperformed. Users are thus more skeptic of journalistic media if they expect the media to adhere to their main public service functions of reporting news in a neutral and precise way (information), of supporting public discourse by mediating between politics and society (public forum), and of monitoring what powerful actors in society do (watchdog), but do not see these expectations properly met in actual media coverage. The same pattern does not emerge with regards to 'analysis' and 'mobilization' functions. In these cases, respondents show similar levels of media trust, regardless of how large the discrepancies are between their expectations for the media to provide comprehensive analysis on complex issues (analysis) and to support political participation (mobilization) and respondents' perceptions of how well these standards are fulfilled. Lastly, 'social empathy' presents a special case in that a higher discrepancy on this dimension is associated with higher instead of lower media trust-a surprising finding that may indicate a certain level of social desirability among respondents when assessing the related items in terms of their individual relevance.

Expectations and evaluations are further linked to both socio-political and media-related characteristics (RQ3a, RQ3b). In terms of citizens' expectations, age shows a positive relationship, as does political interest (see Table 4). Moreover, the more respondents place themselves on the left side of the political ideology scale, the higher their expectations of media performance. Furthermore, all dimensions of populist ideology play a role in citizens' evaluation of the media, but not in a consistent way: Individuals who perceive the people to be a homogenous group have higher expectations and also evaluate media performance more positively. Demand for people's sovereignty goes hand in hand with higher expectations but is not associated with performance evaluations. Anti-elite populist attitudes also come along with higher demands of media performance, but with a more negative perception of actual media performance. For those individuals, increased expectations collide with negative media perceptions. For anti-outgroup attitudes, in contrast, the analyses show a generally negative assessment of professional journalistic media, as they have both lower expectations and more negative perceptions. The expectation-evaluation discrepancy is higher for individuals with lower political interest and with a more right-wing ideology (RQ3c). While homogeneity perceptions regarding the people are related to lower discrepancies, individuals with higher scores on the two populist dimensions 'demand for sovereignty' and 'anti-elite populism' show larger discrepancies between their expectations and perceived media performance.

In comparison to political predispositions, recipients' media use and literacy only play a marginal role with less

Table 3. Linear regression model of the relationship between expectation-evaluation discrepancies and media trust.

\begin{tabular}{|c|c|c|c|c|}
\hline & $\mathrm{b}$ & SE & $\beta$ & $\mathrm{p}$ \\
\hline Constant & 3.182 & .148 & & \\
\hline \multicolumn{5}{|l|}{ Sociodemographics } \\
\hline Gender & .082 & .061 & .041 & .178 \\
\hline Age & .004 & .002 & .059 & .052 \\
\hline Education & .036 & .062 & .017 & .563 \\
\hline Place of residence & -.110 & .083 & -.038 & .186 \\
\hline$\Delta$ Adj. $R^{2}$ & \multicolumn{4}{|c|}{.002} \\
\hline \multicolumn{5}{|c|}{ Expectation-evaluation discrepancies } \\
\hline Information & -.261 & .029 & -.379 & $<.001$ \\
\hline Public forum & -.119 & .051 & -.128 & .020 \\
\hline Watchdog & -.085 & .037 & -.106 & .021 \\
\hline Analysis & -.060 & .047 & -.067 & .203 \\
\hline Social empathy & .082 & .031 & .106 & .008 \\
\hline Mobilization & .005 & .049 & .005 & .920 \\
\hline$\Delta$ Adj. $R^{2}$ & \multicolumn{4}{|c|}{$.291 * * *$} \\
\hline Adj. $R^{2}$ & \multicolumn{4}{|c|}{$.293 * * *$} \\
\hline
\end{tabular}

Notes: $\mathrm{n}=855 ; \mathrm{VIF}<3.7$, Durbin-Watson $=2.01 .^{* * *} \mathrm{p}<.001$. 
Table 4. Explaining citizens' expectations, evaluations, and expectation-evaluation discrepancies of media performance.

\begin{tabular}{|c|c|c|c|}
\hline & Expectations & Evaluations & $\begin{array}{l}\text { Expectation-evaluation } \\
\text { discrepancy }\end{array}$ \\
\hline Constant & $1.966^{* * *}$ & $2.536 * * *$ & -.564 \\
\hline \multicolumn{4}{|l|}{ Sociodemographics } \\
\hline Gender & -.098 & -.103 & .019 \\
\hline Age & $.008^{* * *}$ & .003 & .004 \\
\hline Education & -.037 & -.043 & .005 \\
\hline Place of residence & -.080 & $-.206^{*}$ & .131 \\
\hline$\Delta$ Adj. $R^{2}$ & .062 & .010 & .020 \\
\hline \multicolumn{4}{|l|}{ Political characteristics } \\
\hline Political interest & $.153 * * *$ & .048 & $.109 * *$ \\
\hline Political ideology & $-.044 * * *$ & -.009 & $-.037 * *$ \\
\hline Homogeneity of the people & $.110 * * *$ & $.209 * * *$ & $-.109 * *$ \\
\hline Demand for Sovereignty & $.186 * * *$ & -.002 & $.198 * * *$ \\
\hline Anti-Elite populism & $.101^{* *}$ & $-.255 * * *$ & $.352 * * *$ \\
\hline Anti-outgroup populism & $-.075 * *$ & $-.089 * *$ & .005 \\
\hline$\Delta$ Adj. $\mathrm{R}^{2}$ & .191 & .155 & .186 \\
\hline \multicolumn{4}{|l|}{ Media-related characteristics } \\
\hline Public-service broadcasting & .036 & $.092 * * *$ & -.050 \\
\hline National newspapers and news magazines & -.013 & .041 & .054 \\
\hline Local newspapers & $.049 *$ & .038 & .010 \\
\hline Newspaper websites, news magazines or PSB & $.054^{* *}$ & .021 & .028 \\
\hline Private broadcasting & .002 & .034 & -.028 \\
\hline Tabloid newspapers & -.050 & .035 & $-.088 * *$ \\
\hline Tabloid websites or private broadcasters & -.036 & .016 & -.051 \\
\hline Online user comments & -.003 & $-.091 * * *$ & $.086^{* *}$ \\
\hline Social media channels of influencers, bloggers, or public figures & $.063^{*}$ & .044 & .017 \\
\hline Social media channels of political actors, groups or parties & .015 & .015 & .002 \\
\hline Alternative partisan media & -.015 & -.030 & .016 \\
\hline Partisan selective exposure & -.053 & $.119 * * *$ & $-.161 * * *$ \\
\hline Media knowledge & .022 & .026 & -.007 \\
\hline$\Delta$ Adj. $R^{2}$ & .024 & .071 & .047 \\
\hline Adj. $R^{2}$ & $.277^{* * *}$ & $.236 * * *$ & $.253 * * *$ \\
\hline
\end{tabular}

Notes: Unstandardized b-values. $773 \leq \mathrm{n} \leq 785$; VIF $<2.6$, Durbin-Watson-test: 1.92-2.06. ${ }^{*} \mathrm{p}<.05,{ }^{* *} \mathrm{p}<.01,{ }^{* * *} \mathrm{p}<.001$.

explanatory power (RQ4). However, results show that the information sources recipients use in a high-choice media environment matter for users' evaluation of professional journalistic media. The use of legacy media outlets, local newspapers, and online websites of quality media is related to higher expectations, while public-service broadcasting use is associated with better evaluations of media performance. Those who receive news from sources such as influencers or bloggers also have higher expectations of journalistic media. In contrast, reading online user comments is associated with more negative evaluations of media performance. Finally, exposure to congruent media content is not related to expectations but comes along with more positive views of media performance. Media knowledge does not play a role in explaining both expectations and evaluations. In terms of expectation-evaluation discrepancies, tabloid media use and partisan selective exposure are associated with smaller discrepancies, while heavy use of user comments is related to larger discrepancies (for information on pre- dictors of individual expectation-evaluation discrepancies for each of the six dimensions of normative media functions, see Supplementary File).

In the next step, we were interested in the extent to which expectations and evaluations differ at the level of the six individual dimensions of media functions. We will particularly focus on the impact of political predispositions due to their significant importance in shaping user demands and perceptions. After controlling for sociodemographic variables, the results show that political interest is positively linked to both expectations and evaluations across all six media functions. For political ideology, we find mixed results. Left-wing orientation is consistently associated with higher expectations, but the evaluation of the public forum, analysis, and mobilization functions is independent of political ideology.

Concerning populist attitudes, homogeneity perceptions consistently go along with higher expectations (except for the information function) and more positive evaluations. The more users claim people's sovereignty, 
the higher their expectations of all six media functions. Media performance evaluations, in contrast, are not linked to this populist dimension. In terms of anti-elite populism, results show that higher expectations of individuals supporting anti-elite ideas are only due to higher expectations regarding the media's information and watchdog functions. Yet, negative perceptions of media performance by anti-elitist recipients are directed at all six media functions. In contrast, the overall negative evaluation of the media's role in society by citizens with exclusionary populist attitudes can be traced back to all media functions except the watchdog role (see Table 5).

\section{Discussion}

In today's media environments, professional journalistic news media compete with a vast number of alternative information sources for the attention of the audience. At the same time, journalistic news media face fundamental public criticism, especially voiced by populists. Against this background, the present study had two aims: first, to determine the extent to which civic demands of the media collide with their perceptions of actual media performance, and how this discrepancy is linked to overall media trust; and second, to determine to which extent socio-political predispositions and media-related behaviors are linked to citizens' expectations, evaluations, and expectation-evaluation discrepancies in terms of six media functions: information, public forum, watchdog, analysis, social empathy, and mobilization.

Our study provides systematic insights into how German citizens' expectations regarding normative media functions collide with their evaluations, and how these discrepancies are related to overall media trust. Our findings show that the public has high expectations of the media which they do not see completely fulfilled, and that resulting expectation-evaluation discrepancies are associated with lower levels of media trust, if normative functions are addressed that are of particular relevance to the users and/or perceived as particularly underperformed.

Our study additionally extends earlier research by showing that both expectations and evaluations are linked to populist attitudes. However, increased expectations collided with negative media evaluations only in the case of anti-elite attitudes. For anti-outgroup attitudes, in contrast, the analyses show a generally negative assessment of professional journalistic media, both in terms of expectations and evaluations. This finding confirms the mismatch between this particular populist dimension, representing the anti-pluralistic character of populism, and the normative expectations towards the media in pluralistic societies.

In line with previous research, our study also shows that media expectations and evaluations are strongly related to pre-existing political attitudes. Interestingly, they matter much more than the actual media repertoire. Whether recipients get their news primarily from public- service broadcasters, partisan media or other sources has little impact on how they perceive media performance. Future media trust research should, therefore, add political predispositions more systematically to the equation, in addition to media use as a central concept related to media trust in extant research. Noteworthy, however, is the negative association between the use of online user comments and performance evaluations. This might be due to a dominant representation of dissatisfied users who take advantage of commenting options to publicly criticize established media (e.g., Craft, Vos, \& Wolfgang, 2016; Prochazka \& Schweiger, 2016).

These results have important implications. The fact that a large part of users does not perceive professional journalistic media to fulfill their normative functions, could lead to a further polarization of society. In particular, those recipients who regard politicians as the divisive and malicious elite are also the ones who are disappointed by the media and, hence, do not feel represented by them. Why should they use these media outlets for political news, why should they be willing to pay for their content? They will rather turn to more partisan outlets that are in line with their populist worldviews or avoid political news altogether.

Several limitations of this study need to be acknowledged. Our classification of independent and dependent variables is based on theoretical arguments. We assessed political predispositions, media use, and media knowledge as independent variables. In reality, however, they might also be affected by media perceptions. This reciprocal relationship cannot be addressed by cross-sectional data and calls for longitudinal designs. Moreover, measuring discrepancies between expectations and evaluations comes with some challenges. Most of all, asking individuals to indicate their expectations may negatively affect their performance evaluations (e.g., Park \& Yi, 2016). This is particularly likely when the evaluation dimensions are of high normative relevance and the attitude object is rather vague (Daniller, Allen, Tallevi, \& Mutz, 2017; Webster \& Entwisle, 1976), as is the case with basically desirable journalistic quality dimensions in general reference to 'journalistic media.' Hence, future studies should consider including a greater variety of normatively desirable and undesirable evaluation dimensions to assess the performance of more specific journalistic media outlets.

Overall, however, we hope that our study can shed some light on how user expectations and evaluations of media performance relate to more general perceptions of media trust in the broader context of a politically charged high-choice media environment where journalistic media may find themselves in a growing predicament: Being seen as part of the 'enemy' by a substantial part of society, journalistic media may gradually lose their ability to contribute to social synchronization and to represent all groups of society, which is - from a public service point of view-at the heart of what professional media should aim for in democratic societies. 
Table 5. Explaining citizens' expectations and evaluations of six normative media functions.

\begin{tabular}{|c|c|c|c|c|c|c|c|c|c|c|c|c|}
\hline & \multicolumn{2}{|c|}{ Information } & \multicolumn{2}{|c|}{ Public forum } & \multicolumn{2}{|c|}{ Watchdog } & \multicolumn{2}{|c|}{ Analysis } & \multicolumn{2}{|c|}{ Social empathy } & \multicolumn{2}{|c|}{ Mobilization } \\
\hline & Expectation & Evaluation & Expectation & Evaluation & Expectation & Evaluation & Expectation & Evaluation & Expectation & Evaluation & Expectation & Evaluation \\
\hline Constant & $2.194 * * *$ & $3.654^{* * *}$ & $2.022 * * *$ & $3.046 * * *$ & $1.622 * * *$ & $3.311^{* * *}$ & $2.133^{* * *}$ & $3.300 * * *$ & $2.849 * * *$ & $2.514^{* * *}$ & $1.931^{* * *}$ & $3.188^{* * *}$ \\
\hline Gender & -.143 & -.128 & -.095 & -.126 & .003 & -.115 & -.115 & -.049 & -.115 & -.033 & -.064 & -0.054 \\
\hline Age & $.011 * * *$ & .005 & $.008^{* * *}$ & .004 & $.011 * * *$ & $.01 * * *$ & .007 & .003 & $.006 * *$ & .004 & $.011 * * *$ & $.006 * *$ \\
\hline Education & $.184^{* *}$ & .051 & .007 & .050 & .039 & .056 & -.035 & .016 & -.085 & .096 & .060 & -.001 \\
\hline $\begin{array}{l}\text { Place of } \\
\text { residence }\end{array}$ & -.054 & -.186 & -.102 & $-.241^{*}$ & -.101 & $-.205^{*}$ & -.101 & $-.217^{*}$ & -.105 & -.188 & -.093 & $-.217^{* *}$ \\
\hline$\Delta \operatorname{Adj} . R^{2}$ & .061 & .002 & .041 & .005 & .064 & .020 & .037 & .004 & .027 & .011 & .066 & .011 \\
\hline $\begin{array}{l}\text { Political } \\
\text { interest }\end{array}$ & $.203^{* * *}$ & .042 & $.173^{* * *}$ & $.097^{* *}$ & $.182^{* * *}$ & $.105^{* *}$ & $.211 * * *$ & $.091^{* *}$ & $.131^{* * *}$ & $.155^{* * *}$ & $.272 * * *$ & $.134 * * *$ \\
\hline $\begin{array}{l}\text { Political } \\
\text { ideology }\end{array}$ & -.027 & $-.042 *$ & $-.041 * *$ & -.005 & $-.048^{* *}$ & $-.04 *$ & $-.048^{* *}$ & -.018 & $-.073 * * *$ & $.045^{*}$ & $-.048^{* *}$ & -.007 \\
\hline $\begin{array}{l}\text { Homogeneity } \\
\text { of the people }\end{array}$ & $-.082 *$ & $.327^{* * *}$ & $.161^{* * *}$ & $.288^{* * *}$ & $.049 * * *$ & $.225^{* * *}$ & $.110 * *$ & $.233^{* * *}$ & $.174 * * *$ & $.271 * * *$ & $.079 *$ & $.243 * * *$ \\
\hline $\begin{array}{l}\text { Demand for } \\
\text { Sovereignty }\end{array}$ & $.162^{* * *}$ & .022 & $.206^{* * *}$ & .063 & $.212^{* * *}$ & .031 & $.19 * * *$ & .018 & $.226^{* * *}$ & -.077 & $.197^{* * *}$ & .037 \\
\hline $\begin{array}{l}\text { Anti-Elite } \\
\text { populism }\end{array}$ & $.230 * * *$ & $-.347^{* * *}$ & .058 & $-.307^{* * *}$ & $.18 * * *$ & $-.308 * * *$ & .078 & $-.317^{* * *}$ & .080 & $-.226^{* * *}$ & .057 & $-.318^{* * *}$ \\
\hline $\begin{array}{l}\text { Anti-outgroup } \\
\text { populism }\end{array}$ & $-.080 * *$ & $-.129 * *$ & $-.082 * *$ & $-.104 * *$ & -.023 & -.063 & $-.068 * * *$ & -.053 & $-.217^{* * *}$ & $-.073 *$ & $-.118^{* * *}$ & $-.108^{* *}$ \\
\hline Adj. $R^{2}$ & $.179 * * *$ & $.136 * * *$ & $.190 * * *$ & $.145^{* * *}$ & $.217^{* * *}$ & $.130 * * *$ & $.187^{* * *}$ & $.119 * * *$ & $.205^{* * *}$ & $.124 * * *$ & $.234 * * *$ & $.161 * * *$ \\
\hline
\end{tabular}

Notes: Unstandardized b-values. $755 \leq \mathrm{n} \leq 781$; VIF $<2.05$, Durbin-Watson-test: $1.83-2.10{ }^{*} \mathrm{p}<.05,{ }^{* *} \mathrm{p}<.01,{ }^{* * *} \mathrm{p}<.001$. 


\section{Conflict of Interests}

The authors declare no conflict of interest.

\section{Supplementary Material}

Supplementary material for this article is available online in the format provided by the author (unedited).

\section{References}

Arlt, D., \& Wolling, J. (2018). Bias wanted! Examining people's information exposure, quality expectations and bias perceptions in the context of the refugees debate among different segments of the German population. Communications, 43(1), 75-99.

Arnold, K. (2009). Qualitätsjournalismus. Die Zeitung und ihr Publikum [Quality journalism: The newspaper and its audience]. Konstanz: UVK.

Ashley, S., Poepsel, M., \& Willis, E. (2010). Media literacy and news credibility: Does knowledge of media ownership increase skepticism in news consumers? Journal of Media Literacy Education, 2(1), 37-46.

BR. (2016). Medien in der Glaubwürdigkeitskrise? [The media in credibility crisis?]. BR. Retrieved from http://www.br.de/presse/inhalt/pressemitteilungen/ glaubwuerdigkeitsstudie-br-b5-geburtstag-100.html

Chomsky, N. (2002). Media control: The spectacular achievements of propaganda (2nd ed.). New York, NY: Seven Stories Press.

Cook, T. E., \& Gronke, P. (2001). The dimensions of institutional trust. How distinct is public confidence in the media? Paper presented at 59th Annual Meeting of the Midwest Political Science Association, Chicago, IL, USA.

Craft, S., Vos, T. P., \& Wolfgang, J. D. (2016). Reader comments as press criticism: Implications for the journalistic field. Journalism, 17(6), 677-693.

Daniller, A., Allen, D., Tallevi, A., \& Mutz, D. C. (2017). Measuring trust in the press in a changing media environment. Communication Methods and Measures, 11(1), 76-85.

Donsbach, W., Rentsch, M., Schielicke, A. M., \& Degen, S. (2009). Entzauberung eines Berufs. Was die Deutschen vom Journalismus erwarten und wie sie enttäuscht werden [Disenchantment of a profession: What Germans expect from journalism and how they are being let down]. Konstanz: UVK.

Eberl, J.-M., \& Riedl, A. (2020). Citizen's expectations of journalism: What's politics got to do with it? Paper presented at the Annual Conference of the German Communication Association, Munich, Germany.

Fawzi, N. (2019). Untrustworthy news and the media as "enemy of the people?" How a populist worldview shapes recipients' attitudes toward the media. The International Journal of Press/Politics, 24(2), 146-164.

Gil de Zúñiga, H., \& Hinsley, A. (2013). The press versus the public: What is "good journalism?" Journalism Studies, 14(6), 926-942.

Graber, D. (2003). The media and democracy: Beyond myths and stereotypes. Annual Review of Political Science, 6(1), 139-160.

Gunther, A. (1988). Attitude extremity and trust in media. Journalism Quarterly, 65(2), 279-287. https:// doi.org/10.1177/107769908806500203

Guo, Z. S., \& Li, L. (2011). Perceptions of media functions and processing of news: Analysis of audience in a Chinese metropolis. Asian Journal of Communication, 21(1), 47-68. https://doi.org/10.1080/ 01292986.2010 .524231

Hameleers, M., Bos, L., \& de Vreese, C. H. (2017). The appeal of media populism: The media preferences of citizens with populist attitudes. Mass Communication \& Society, 20(4), 481-504. https://doi.org/10.1080/ 15205436.2017.1291817

Hanitzsch, T. (2011). Populist disseminators, detached watchdogs, critical change agents and opportunist facilitators: Professional milieus, the journalistic field and autonomy in 18 countries. International Communication Gazette, 73(6), 477-494. https://doi.org/ $10.1177 / 1748048511412279$

Hanitzsch, T., van Dalen, A., \& Steindl, N. (2018). Caught in the nexus. A comparative and longitudinal analysis of public trust in the press. International Journal of Press/Politics, 23(1), 3-23.

Heider, D., McCombs, M., \& Poindexter, P. M. (2005). What the public expects of local news: Views on public and traditional journalism. Journalism \& Mass Communication Quarterly, 82(4), 952-967.

Heise, N., Loosen, W., Reimer, J., \& Schmidt, J.-H. (2014). Including the audience: Comparing the attitudes and expectations of journalists and users towards participation in German TV news journalism. Journalism Studies, 15(4), 411-430.

Hölig, S., Loosen, W., \& Reimer, J. (2020). What journalists want and what they ought to do. (In)Congruencies between journalists' role conceptions and audiences' expectations. Presented at the Annual Conference of the German Communication Association, Munich.

Holt, K., Figenschou, T. U., \& Frischlich, L. (2019). Key dimensions of alternative news media. Digital Journalism, 7(7), 860-869.

Hopmann, D. N., Shehata, A., \& Strömbäck, J. (2015). Contagious media effects: How media use and exposure to game-framed news influence media trust. Mass Communication and Society, 18(6), 776-798.

Jackob, N., Schultz, T., Jakobs, I., Ziegele, M., Quiring, O., \& Schemer, C. (2019). Medienvertrauen im Zeitalter der Polarisierung [Media trust in times of polarization]. Media Perspektiven, 5, 210-220.

Jagers, J., \& Walgrave, S. (2007). Populism as political communication style: An empirical study of political parties' discourse in Belgium. European Journal of Political Research, 46(3), 319-345. 
Jandura, O., \& Friedrich, K. (2014). The quality of political media coverage. In C. Reinemann (Ed.), Political communication (Vol. 18, pp. 351-373). Berlin and Boston, MA: De Gruyter Mouton.

Kalogeropoulos, A., Suiter, J., Udris, L., \& Eisenegger, M. (2019). News media trust and news consumption: Factors related to trust in news in 35 countries. International Journal of Communication, 13, 3672-3693.

Karlsson, M., \& Clerwall, C. (2019). Cornerstones in journalism: According to citizens. Journalism Studies, 20(8), 1184-1199.

Kaun, A. (2014). 'I really don't like them!' Exploring citizens' media criticism. European Journal of Cultural Studies, 17(5), 489-506.

Kohring, M., \& Matthes, J. (2007). Trust in news media: Development and validation of a multidimensional scale. Communication Research, 34(2), 231-252.

Ladd, J. M. (2012). Why Americans hate the media and how it matters. Princeton, NJ: Princeton University Press.

Lambe, J. L., Caplan, S. E., Cai, X., \& Signorielli, N. (2004). Public perceptions of media performance at the beginning of the war on terrorism. Communication Research Reports, 21(3), 299-309.

Lee, T.-T. (2010). Why they don't trust the media: An examination of factors predicting trust. American Behavioral Scientist, 54(1), 8-21. https://doi.org/ 10.1177/0002764210376308

Livingstone, S. (2004). Media literacy and the challenge of new information and communication technologies. The Communication Review, 7(1), 3-14.

Martens, H., \& Hobbs, R. (2015). How media literacy supports civic engagement in a digital age. Atlantic Journal of Communication, 23(2), 120-137.

McQuail, D. (1992). Media performance: Mass communication and the public interest. London: Sage.

Mellado, C., Mothes, C., Hallin, D. C., Humanes, M. L., Lauber, M., Mick, J., . . . Davydov, S. (2020). Investigating the gap between newspaper journalists' role conceptions and role performance in nine European, Asian, and Latin American countries. International Journal of Press/Politics. Advance online publication. https://doi.org/10.1177/1940161220910106

Mitchell, A., Simmons, K., Matsa, K. E., Silver, L., Shearer, E., Johnson, C., . . . Taylor, K. (2018). In Western Europe, public attitudes toward news media more divided by populist views than left-right ideology. Pew Research Center. Retrieved from http:// www.journalism.org/2018/05/14/in-westerneurope-public-attitudes-toward-news-media-moredivided-by-populist-views-than-left-right-ideology

Mothes, C. (2017). Biased objectivity: An experiment on information preferences of journalists and citizens. Journalism \& Mass Communication Quarterly, 94(4), 1073-1095.

Müller, J. (2013). Mechanisms of trust. News media in democratic and authoritarian regimes. Frankfurt am Main: Campus.
Newman, N., Fletcher, R., Kalogeropoulos, A., \& Nielsen, R. (2019). Reuters institute digital news report 2019. Oxford: Reuters Institute for the Study of Journalism.

Norris, P. (2000). The impact of television on civic malaise. In S. J. Pharr \& R. D. Putnam (Eds.), Disaffected democracies. What's troubling the trilateral countries? (pp. 231-251). Chichester: Princeton University Press.

Park, S.-J., \& Yi, Y. (2016). Performance-only measures vs. performance-expectation measures of service quality. The Service Industries Journal, 36(15/16), 741-756.

Peifer, J. T. (2018). Perceived news media importance: Developing and validating a measure for personal valuations of normative journalistic functions. Communication Methods and Measures, 12(1), 55-79.

Prochazka, F. (2020). Vertrauen in Journalismus unter Online-Bedingungen. Zum Einfluss von Personenmerkmalen, Qualitätswahrnehmungen und Nachrichtennutzung [Trust in journalism in online environments. The influence of personal characteristics, quality perceptions and news media use]. Wiesbaden: Springer.

Prochazka, F., \& Schweiger, W. (2016). Medienkritik online: Was kommentierende Nutzer am Journalismus kritisieren [Media criticism online: What commenting users criticize about journalism]. SCM Studies in Communication / Media, 5(4), 454-469. https://doi. org/10.5771/2192-4007-2016-4-454

Schielicke, A. M., Mothes, C., \& Donsbach, W. (2014). Vertrauen in Journalismus. Trends \& Einflussfaktoren [Trust in journalism: Trends and influences]. In B. Stark, O. Quiring, \& N. Jackob (Eds.), Von der Gutenberg-Galaxis zur Google-Galaxis. Alte und neue Grenzvermessungen nach 50 Jahren DGPUK [From Gutenberg Galaxy to Google Galaxy: Old and new boundary markers after 50 years of DGPuK] (pp. 247-269). Konstanz: UVK.

Schudson, M. (2008). Why democracies need an unlovable press. Malden, MA: Polity Press.

Schulz, A., Müller, P., Schemer, C., Wirz, D. S., Wettstein, M., \& Wirth, W. (2017). Measuring populist attitudes on three dimensions. International Journal of Public Opinion Research, 30(2), 316-326. https://doi.org/ 10.1093/ijpor/edw037

Schulz, A., Wirth, W., \& Müller, P. (2020). We are the people and you are fake news: A social identity approach to populist citizens' false consensus and hostile media perceptions. Communication Research, 20(2), 201-226. https://doi.org/10.1177/ 0093650218794854

Strömbäck, J. (2005). In search of a standard: Four models of democracy and their normative implications for journalism. Journalism Studies, 6(3), 331-345.

Tandoc, E. C., \& Duffy, A. (2016). Keeping up with the audiences: Journalistic role expectations in Singapore. International Journal of Communication, 10, 3338-3358. 
Tsfati, Y. (2016). A new measure for the tendency to select ideologically congruent political information: Scale development and validation. International Journal of Communication, 10, 200-225.

Tsfati, Y., \& Ariely, G. (2014). Individual and contextual correlates of trust in media across 44 countries. Communication Research, 41(6), 760-782. https:// doi.org/10.1177/0093650213485972

Tsfati, Y., \& Cappella, J. N. (2003). Do people watch what they do not trust? Exploring the association between news media skepticism and exposure. Communication Research, 30(5), 504-529.

Tsfati, Y., \& Peri, Y. (2006). Mainstream media skepticism and exposure to sectorial and extranational news media: The case of Israel. Mass Communication \& Society, 9(2), 165-187.

Tsfati, Y., Meyers, O., \& Peri, Y. (2006). What is good journalism? Comparing Israeli public and journalists' perspectives. Journalism, 7(2), 152-173. https://doi. org/10.1177/1464884906062603

Urban, J., \& Schweiger, W. (2014). News quality from the recipients' perspective. Journalism Studies, 15(6), 821-840. https://doi.org/10.1080/1461670X. 2013.856670

van der Wurff, R., \& Schönbach, K. (2014). Civic and cit- izen demands of news media and journalists: What does the audience expect from good journalism? Journalism \& Mass Communication Quarterly, 91(3), 1-19.

Vos, T. P., Eichholz, M., \& Karaliova, T. (2019). Audiences and journalistic capital: Roles of journalism. Journalism Studies, 20(7), 1009-1027.

Vraga, E. K., Tully, M., Akin, H., \& Rojas, H. (2012). Modifying perceptions of hostility and credibility of news coverage of an environmental controversy through media literacy. Journalism, 13(7), 942-959. https:// doi.org/10.1177/1464884912455906

Weaver, D. H., Beam, R. A., Brownlee, B. J., Voakes, P. S., \& Wilhoit, G. C. (2006). The American journalist in the 21st century: US news people at the dawn of a new millennium. New York, NY: Routledge.

Webster, M., Jr., \& Entwisle, D. R. (1976). Expectation effects on performance evaluations. Social Forces, 55(2), 493-502.

Wolling, J. (2004). Qualitätserwartungen, Qualitätswahrnehmungen und die Nutzung von Fernsehserien [Quality expectations, quality perceptions, and the use of TV serials]. Publizistik, 49(2), 171-193. https://doi.org/10.1007/s11616004-0035-y

\section{About the Authors}

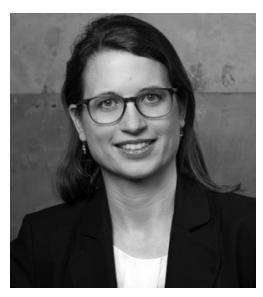

Nayla Fawzi is a Postdoctoral Researcher at the Department of Communication and Media at LudwigMaximilians-University of Munich. Her research focuses on media trust and media performance, media and populism, and online user behavior. She was a member of the COST Action "Populist political communication in Europe." During spring term 2019, she was a Guest Professor at TU Dresden. Nayla Fawzi is Head of the scientific network "Media trust in the digitalized world."

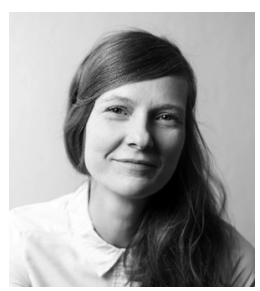

Cornelia Mothes is a Professor of media management and journalism at Macromedia University of Applied Sciences in Leipzig, Germany. Her main research interests lie in the field of political communication, journalism, and media psychology, with a focus on experimental research testing communication strategies to increase political tolerance and participation in digital democracies. Cornelia is a member of the international project "Journalistic Role Performance" and serves as WAPOR's national representative for Germany. 